\title{
Correction to: A Cross-cultural Perspective on Intrathecal Opioid Therapy Between German and Iranian Patients
}

\author{
Barbara Kleinmann ${ }^{1}$ - Nayereh Khodashenas Firoozabadi ${ }^{2}$. \\ Tilman Wolter ${ }^{1}$
}

Published online: 5 October 2021

(C) The Author(s) 2021

\section{Correction to: Cult Med Psychiatry (2021) 45:218-233 https://doi.org/10.1007/s11013-020-09682-6}

The article "A Cross-cultural Perspective on Intrathecal Opioid Therapy Between German and Iranian Patients", written by Barbara Kleinmann · Nayereh Khodashenas Firoozabadi - Tilman Wolter was originally published electronically on the publisher's internet portal on 28th July 2020 without open access. With the author(s)' decision to opt for Open Choice the copyright of the article changed on 1st September 2021 to (C) The Author(s) 2021 and the article is forthwith distributed under a Creative Commons Attribution.

The original article has been corrected.

Open Access This article is licensed under a Creative Commons Attribution 4.0 International License, which permits use, sharing, adaptation, distribution and reproduction in any medium or format, as long as you give appropriate credit to the original author(s) and the source, provide a link to the Creative Commons licence, and indicate if changes were made. The images or other third party material in this article are included in the article's Creative Commons licence, unless indicated otherwise in a credit line to the material. If material is not included in the article's Creative Commons licence and your intended use is not permitted by statutory regulation or exceeds the permitted use, you will need to obtain

The original article can be found online at https://doi.org/10.1007/s11013-020-09682-6.

Tilman Wolter

tilman.wolter@uniklinik-freiburg.de

1 Interdisciplinary Pain Center, Medical Center, Faculty of Medicine, University of Freiburg, University of Freiburg, Breisacherstr. 64, 79106 Freiburg, Germany

2 Department of Anesthesiology, Pain Clinic, Khatam Ol Anbia Hospital, Tehran, Islamic Republic of Iran 
permission directly from the copyright holder. To view a copy of this licence, visit http:// creativecommons.org/licenses/by/4.0/.

Publisher's Note Springer Nature remains neutral with regard to jurisdictional claims in published maps and institutional affiliations. 